\title{
Antimicrobial activity of four different dental gel formulas on cariogenic bacteria evaluated using the linear regression method
}

\author{
Nádia Araci Bou-Chacra*, Sandra Sayuri Gobi, Mitsuko Taba Ohara, \\ Terezinha de Jesus Andreoli Pinto
}

Departamento de Farmácia, Faculdade de Ciências Farmacêuticas, Universidade de São Paulo

*Correspondence:

N. A. Bou-Chacra

Av. Prof. Lineu Prestes, 580 - Bl. 13A Cidade Universitária - CEP 05508-900 São Paulo - SP

E-mail: chacra@usp.br
The antimicrobial activity of four different dental gel formulas was evaluated on three microorganisms associated with cariogenesis: Streptococcus mutans, Lactobacillus casei and Actinomyces viscosus. The preliminary antimicrobial activity evaluation was performed using an agar diffusion method. In addition, the formulas were challenged using each microorganism with subsequent determinations of survivors at time intervals of 1, 5, 10, 20 and 30 minutes. The decimal reduction time (D-value) calculated from the obtained curves (logCFU/mL vs. time) was employed for the antimicrobial activity comparison of the formulas. The selected method for survivor enumeration was validated according to official compendia. Results revealed intense bactericidal activity, even at 1:2 dilution, on $\mathrm{S}$. mutans and $\mathrm{L}$. casei. The data concerning A. viscosus showed the absence of microbial reduction in the challenge employing diluted formulas at the selected time interval. The obtained D-values were 0.21, 2.08, 1.93 and 5.79 minutes for formulas 1, 2, 3 and 4, respectively. After comparing the obtained results, formula 1 can be considered to have the highest bactericidal activity.

\section{INTRODUCTION}

The incorporation of antimicrobial substances in cosmetics and personal hygiene products can prevent strong corporal malodor and slight cutaneous infections that are originated from resident microbiota activity. Such products are meant not only to clean, but also to perfume or alter appearance, correct personal malodors and/or protect or keep the skin in good condition as defined by directive $93 / 35 / \mathrm{EEC}$, the sixth amendment to the original cosmetic directive of 1976 (CTPA, 2004).

According to Brazilian legislation (ANVISA - RDC $\left.\mathrm{n}^{\circ} 79,2000\right)$, antiseptics are defined as a product unto which substances, destined to clean and/or protect the skin mucosa are added, that prevent and fight malodors, caused by microorganisms, by inhibiting their growth or by destroying them.

Antiseptic compounds can be used in different 
cosmetics and personal hygiene products, such as: antiseptic soap, anti-dandruff shampoos, conditioners and lotions, antiplaque, anti-cavity and anti-calculus dentifrices, antiseptic oral rinses, antiseptic talc, antiacne products, and deodorants (Wilkinson, Moore, 1990). Coal tar, triclosan, chlorhexidine, quaternary ammonium compounds, and cetylpyridinium chloride are some of the antimicrobials used in these products. Some preservatives can also act as antiseptics, depending on their concentration.

With regard to oral products, the use of formaldehyde as a preservative, with a maximum concentration of $0.1 \%$, was regulated in Brazil by ANVISA - RDC $n^{\circ} 79$, in spite of its carcinogenicity (Soffritti et al., 2002).

Essential oils, such as eucalyptol, menthol and thymol, frequently used for flavoring in oral products, can also contribute to the antiseptic properties of these products. The inhibitory properties of natural substances such as hinokitiol, cinnamon bark oil, papua-mace extracts and clove bud oil in spice extracts were previously demonstrated against oral bacteria (Saeki et al., 1989).

When these substances are added to oral products, they kill microorganisms by disrupting their cell walls and inhibiting their enzymic activity. They prevent bacterial aggregation, slow multiplication and release endotoxins (Nascimento et al., 2000). These compounds, when added to mouth rinse, have proved to be "at least as good as" dental floss for the control of interproximal gingivitis. The essential oil in mouth rinse was significantly more effective (Sharma et al., 2002), although antimicrobial activity depended on the type and the concentration of the oil, as well as the test's microbial strain (Mangena, Muyiam, 1999; Nostro et al., 2002).

However, the use of these oils can adversely affect the consumer. Acute stomatitis resulting from a popular toothpaste containing cinnamon oil flavor has been reported. This essential oil is known as a topical sensitizer and was shown to be the offending allergen (Drake, Maibach, 1976; Sainio, Kanerva, 1995).

The benefits of introducing antibacterial agents in cosmetics and hygiene products have been seriously questioned in recent years. As a consequence, recommendations and even laws have been introduced concerning the regulation of certain germicides being used. In Brazil, cosmetics and hygiene products containing antimicrobial substances are considered to be a class 2 risk (potential risk) for safety (ANVISA -RDC $\left.\mathrm{n}^{\circ} 79,2000\right)$.

The oral cavity is a highly contaminated area. It has approximately $10^{8}$ bacteria/mL of saliva. Streptococcus sp., Neisseria sp., Veillonella sp., Actinomyces sp., and Lactobacillus sp. are more often related to cariogenesis
(Marchant, 2001; Zambom, Kasprzak, 1995), whose incidence can be related to socioeconomic conditions (Baldani, Narval, Antunes, 2002).

When evaluating the antimicrobial activity of cosmetics and products containing antiseptics, the resident and transient microorganisms should be used as challenging microorganisms. Thus, an oral hygiene product should be tested against microorganisms related to root surface and enamel caries, such as Streptococcus mutans, Lactobacillus sp., and Actinomyces viscosus.

Assays to test antimicrobial activity are generally based on agar diffusion (Cooper et al., 1974; Barry, Thornsberry, 1991) and on their minimum inhibitory concentration (Candido, Azevedo, Ito, 1996; Pozzobon, Bandeira, Pizzolitto, 2000). Although the diffusion method is advantageous, as it allows for easy manipulation and quick results, it may also be limited by the antimicrobial agent's solubility. The method's limitation was demonstrated by Pozzobon, Bandeira and Pizzolitto (2000) and Bandeira et al. (1999), who tested six different antiseptic solutions against $S$. mutans, L. acidophilus, $A$. viscosus and mixed cultures. The results were not in accordance with those obtained in the minimum inhibition concentration (MIC) test, since the samples that presented higher inhibition zones did not present lower MIC.

The MIC determination allows for the evaluation of antimicrobial activity and can be used as a quantitative parameter for comparison among different formulas. However, this assay cannot provide the microbial death profile $(\log \mathrm{CFU} / \mathrm{mL}$ vs. time), important data when evaluating product behavior during the utilization period.

In 1979, in order to obtain the microbial death profile, Orth proposed the linear regression method to evaluate preservative systems in cosmetics. This evaluation was performed by calculating the decimal reduction time (Dvalue). The same mathematical model was employed to evaluate the efficacy of preservative systems in sterile drugs (Akers, Boand, Binkley, 1984) as well as in pharmaceutical products with antibiotics (Mattie, 1981; Tsuji et al., 1984), based on the dogma that microbes die following a first order process.

The objective of this study was to evaluate the antimicrobial activity of four different dental gel formulas on $S$. mutans, L. casei and A. viscosus using the linear regression method.

\section{MATERIALS AND METHODS}

The material of this study consisted of four different dental gel formulas identified as formulas 1, 2, 3 and 4. The four formulas presented the same base formula: 
sorbitol, silica, polyethylene glycol (PEG-32), sodium lauryl sulfate, cellulose gum, sodium saccharin and formaldehyde, as described on the package. Each formula had different flavors described as original red (formula1), eucalyptus mint (formula 2), menta mint (formula 3 ) and lemon mint (formula 4) and different colorants. Furthermore, formulas 1, 2 and 3 contained the same active ingredient: sodium fluoride $(\mathrm{NaF}) 0.32 \% \mathrm{p} / \mathrm{p}$ (1500 ppm of ion fluoride). Formula 4 contained sodium monofluorophosphate $\left(\mathrm{Na}_{2} \mathrm{PO}_{3} \mathrm{~F}\right)$ at a concentration equal to $0.8 \% \mathrm{p} / \mathrm{p}$ (1000 ppm of ion fluoride).

\section{Methods}

\section{Bacterial Inocula}

The Actinomyces viscosus, Pennsylvania University, Streptococcus mutans ATCC 25175 and Lactobacillus casei ATCC 7469 strains were transferred into a tube containing Brain Heart Infusion agar (BHIA) (Difco ${ }^{\circledR}$ ). The incubation conditions were as follows: $37^{\circ} \mathrm{C}$, for 24 hours in a microaerophillic environment $\left(10 \% \mathrm{CO}_{2}\right)$, employing a Probac ${ }^{\circledR}$ jar for the latter two microorganisms, and normal conditions for the first one. The cellular mass that was obtained was recovered by transferring $5 \mathrm{~mL}$ of sterile saline solution to the tube containing the microorganism on the media surface and gentle shaking. Each microbial suspension underwent the assay for determining viable bacteria using a pour-plate technique (USP, 2000), with BHIA. Plates were incubated at $37^{\circ} \mathrm{C}$ for 72 hours under the same above mentioned conditions. After incubation, bacterial growth was covered with $5 \mathrm{~mL}$ of $1 \%$ agar with $0.1 \%(\mathrm{w} / \mathrm{v})$ of tryphenyl-tetrazolium chloride (TTC) $\left(\right.$ Sigma $\left.^{\mathbb{R}}\right)$. After an additional hour of incubation, red colonies were counted (CFU/mL) (Ohara, 1992). The microbial suspensions were stocked for 24 hours under refrigeration. Prior to their use in tests, the suspensions were diluted to $<100 \mathrm{CFU} / \mathrm{mL}$.

\section{Validation of the Method for Estimating the Number of Viable Microorganisms}

One $\mathrm{mL}$ aliquots of 1:2 and 1:10 dilutions of samples in a sterile saline solution, and $0.5 \mathrm{~mL}$ of microbial suspension containing less than $100 \mathrm{CFU}$ were transferred to Petri dishes. Then, the aliquots were mixed with $15 \mathrm{~mL}$ of BHIA. The assay sequence was the same as the one described for determining viable microorganisms. The assay was performed in triplicate for each microorganism and dilution. The control assays were also performed in parallel, by transferring $0.5 \mathrm{ml}$ of each microbial suspension to Petri dishes using $15 \mathrm{~mL}$ of BHIA.

\section{Estimating the Number of Viable Microorganisms}

The viable mesophile bacteria and fungi in the formulas were determined by the pour-plate method (USP, 2000). One $\mathrm{mL}$ aliquots of 1:10 and 1:100 dilutions of the product in saline solution were transferred to two series of Petri dishes, in triplicate. The first set was homogenized with $15 \mathrm{~mL}$ of soybean-casein digest agar (TSA) and the other with $15 \mathrm{~mL}$ of Sabouraud dextrose agar (SDA) $\left(\right.$ Difco $\left.^{\circledR}\right)$. Plates were incubated at $32 \pm 2.5^{\circ} \mathrm{C}$ and $22 \pm 2.5^{\circ} \mathrm{C}$ for bacteria and fungi, respectively. After incubation, growth was covered with $5 \mathrm{~mL}$ of TTC gel over the surface according to Ohara (1992). The plates were reincubated at $32 \pm 2.5^{\circ} \mathrm{C}$ for 60 minutes, with posterior counting of red colonies $(\mathrm{CFU} / \mathrm{mL})$. The same procedures were also performed using BHIA, and incubated at $37 \pm 0.5^{\circ} \mathrm{C}$ for 72 hours, under normal and microaerophillic environments $\left(10 \% \mathrm{CO}_{2}\right)$.

\section{Preliminary Assay to Verify Antimicrobial Activity Using the Agar Diffusion Method}

Ten grams of each sample were transferred to a flask containing $10 \mathrm{~mL}$ of sterile saline solution and homogenized for 2 minutes using a vortex mixer. Fifteen mL of BHIA were transferred to Petri dishes, and after medium solidification, $5 \mathrm{~mL}$ of the same medium were inoculated with a $0.5 \%(\mathrm{v} / \mathrm{v})$ microbial suspension, containing approximately $10^{8} \mathrm{CFU} / \mathrm{mL}$ of the mentioned microorganisms. After solidification, $100 \mu \mathrm{L}$ of each diluted sample (1:2) were applied to the medium surface using a template containing six previously sterilized wells. One Petri dish was used for each microorganism and sample, for a total of 12 assays with 6 replicates, contemplating four products and three microorganisms: A. viscosus, S. mutans ATCC 25175, L. casei ATCC 7469. Plates were incubated at $37 \pm 0.5^{\circ} \mathrm{C}$, for 24 hours, in a microaerophillic atmosphere employing Probac ${ }^{\circledR}$ jars, except for the assays related to A. viscosus, which were incubated in a normal atmosphere. After this period, $5 \mathrm{~mL}$ of agar $(1 \%)$ with $0.1 \%(\mathrm{v} / \mathrm{v})$ TTC were transferred to the plate. The plates were incubated for additional 60 minutes before observation of the inhibition zone (Ohara, 1992).

\section{Evaluation of Antimicrobial Activity Using the Linear Regression Method}

Aliquots of $0.1 \mathrm{~mL}$ of the standardized microbial suspensions (approximately $10^{10} \mathrm{CFU} / \mathrm{mL}$ ) of each microorganism were transferred in isolated fashion to two 
tubes, one with $10 \mathrm{~g}$ of undiluted sample and the other with $10 \mathrm{~mL}$ of diluted sample (1:2), for a total of 24 assays (four undiluted samples, four diluted samples (1:2) for three microorganisms).

After homogenization by manual stirring for 1 minute, the viable microorganisms were immediately counted using the pour-plate method with $1 \mathrm{~g}$ for the undiluted samples and $1 \mathrm{~mL}$ for the diluted samples. The decimal dilution series were performed employing $9 \mathrm{~mL}$ of the sterile saline solution. After 5, 10, 20 and 30 minutes the same procedures were repeated. The incubation conditions and the procedures for enumerating the colonies were the same as described above.

\section{$\mathrm{pH}$ determination of the formulas}

The $\mathrm{pH}$ was measured using a HANNA $\mathrm{pH}$ meter and an ORION semi-micro $\mathrm{pH}$ electrode (Orion Research Incorporated, Boston, $\mathrm{MA}$ ). The $\mathrm{pH}$ levels for the four dental gel formulas were taken after a 1:2 dilution using sterile distilled water.

The $\mathrm{pH}$ meter was initially standardized using J.T. Baker buffered solutions of pH 4 and 7 (Mallinckrodt Baker, Inc., Phillipsburg, NJ). It was re-calibrated before testing each new product. All products were tested in triplicate to obtain mean $\mathrm{pH}$ values. The products were in contact with the $\mathrm{pH}$ electrode for 10 minutes at a room temperature of $21^{\circ} \mathrm{C} \pm 2{ }^{\circ} \mathrm{C}$ to allow the $\mathrm{pH}$ value to stabilize. The electrode was thoroughly washed between samples using a stream of water to remove all traces of the previous sample. The electrode was then rinsed with distilled water and dried with a TX 612 wiper (Texwipe, Upper Saddle River, NJ).

\section{RESULTS AND DISCUSSION}

\section{Validation of the viable microorganism enumeration method}

Table I shows a high recovery rate of microorganisms in the adopted condition. Data superior to $88 \%$ were obtained in the lowest dilution (1:2). The rates from a 1:10 dilution, when inferior to those obtained for the lowest dilution could have resulted from variations of the employed method.

According to the official recommendation (USP, 2000 ), a rate greater than a $75 \%$ recovery in microbiological validation tests shows the absence of antimicrobial activity in the assay. Thus, the selected method for enumerating challenging microorganisms can be considered validated.

TABLE I - Recovery Rates of A. viscosus, L. casei, S. mutans in the Assay for Determining the Viable Microorganisms Validation for the Formulas 1, 2, 3 and 4

\begin{tabular}{|c|c|c|c|c|c|c|c|c|}
\hline \multirow[t]{3}{*}{ Formulas } & \multirow{2}{*}{\multicolumn{2}{|c|}{$\begin{array}{l}\text { Control } \\
\text { CFU/assay }\end{array}$}} & \multirow{2}{*}{\multicolumn{3}{|c|}{$\begin{array}{l}\text { Diluted Sample (1:2) } \\
\text { CFU/assay }\end{array}$}} & \multirow{2}{*}{\multicolumn{3}{|c|}{$\begin{array}{l}\text { Diluted Sample (1:10) } \\
\text { CFU/assay }\end{array}$}} \\
\hline & & & & & & & & \\
\hline & Replicate & Average & Replicate & Average & $\mathrm{R}(\%)$ & Replicate & Average & $\mathbf{R}(\%)$ \\
\hline \multicolumn{9}{|l|}{1} \\
\hline Actinomyces viscosus & $51 / 48 / 46$ & 48 & $47 / 47 / 48$ & 47 & 97.9 & $48 / 44 / 45$ & 45 & 93.8 \\
\hline Lactobacillus casei & $42 / 41 / 43$ & 42 & $46 / 46 / 42$ & 44 & 100 & $35 / 40 / 38$ & 37 & 77.1 \\
\hline $\begin{array}{l}\text { Streptococcus mutans } \\
2\end{array}$ & $41 / 46 / 48$ & 45 & $45 / 44 / 45$ & 45 & 100 & $35 / 36 / 46$ & 39 & 86.7 \\
\hline Actinomyces viscosus & $51 / 48 / 46$ & 48 & $39 / 50 / 49$ & 46 & 95.8 & $45 / 45 / 40$ & 43 & 89.6 \\
\hline Lactobacillus casei & $42 / 41 / 43$ & 42 & $41 / 42 / 42$ & 42 & 100 & $39 / 40 / 40$ & 40 & 95.2 \\
\hline $\begin{array}{l}\text { Streptococcus mutans } \\
3\end{array}$ & $41 / 46 / 48$ & 45 & $44 / 48 / 46$ & 46 & 100 & $41 / 45 / 39$ & 41 & 91.1 \\
\hline Actinomyces viscosus & $51 / 48 / 46$ & 48 & $49 / 50 / 48$ & 49 & 100 & $50 / 50 / 48$ & 49 & 100 \\
\hline Lactobacillus casei & $42 / 41 / 43$ & 42 & $49 / 44 / 40$ & 44 & 100 & $40 / 40 / 39$ & 40 & 90.9 \\
\hline $\begin{array}{l}\text { Streptococcus mutans } \\
4\end{array}$ & $41 / 46 / 48$ & 45 & $42 / 39 / 44$ & 41 & 91.1 & $37 / 45 / 44$ & 42 & 95.5 \\
\hline Actinomyces viscosus & $51 / 48 / 46$ & 48 & $50 / 51 / 51$ & 51 & 100 & $49 / 52 / 53$ & 51 & 100 \\
\hline Lactobacillus casei & $42 / 41 / 43$ & 42 & $39 / 41 / 42$ & 40 & 95.2 & $40 / 43 / 40$ & 41 & 97.6 \\
\hline Streptococcus mutans & $41 / 46 / 48$ & 45 & $35 / 43 / 42$ & 40 & 88.9 & $40 / 45 / 48$ & 44 & 100 \\
\hline
\end{tabular}




\section{Estimating the Number of Viable Microorganisms}

The evaluation revealed a bioburden $<10 \mathrm{CFU} / \mathrm{mL}$ in all samples. Such data indicate adequate microbiological quality of the tested products, according to official recommendations (ANVISA - RDC n 481, 1999).

\section{Preliminary Evaluation of Antimicrobial Activity Through the Agar Diffusion Method}

The diffusion method can be used as a preliminary test for detecting antimicrobial activity in substances or products. Since the diffusion phenomenon depends on each substance's physical-chemical properties, as for example its diffusion coefficient, as well as the medium where the diffusion occurs (Barry, Thornsberry, 1991), it is possible to obtain a qualitative indication of antimicrobial activity.

Therefore, the inhibition zone diameter measurements cannot be considered to be a comparative parameter when different formulations are tested, nor can the absence of antimicrobial activity be assured when the inhibition zone is not formed. The assays showed antimicrobial activity in all tested samples with different inhibition zone diameters (Figure 1). The dye (TTC) employed for a better zone contrast in the assay was only efficient for $A$. viscosus, showing a red color when reduced to formazan in alkaline $\mathrm{pH}$ (Mattson, Jensen, Dutcher, 1947). The absence of a red color could be due to the assay conditions or even some microorganism characteristics, such as the absence of a specific enzymatic system (Rioux, Bastide, Galzy, 1960) and medium acidification. Since $S$. mutans and $L$. casei produce acid compounds from glucose present in BHIA, the absence of color for a TTC reaction was expected.

\section{Evaluation of Antimicrobial Activity}

Tables II and III, as well Figure 2, present data related to $A$. viscosus. The non-diluted samples showed a reduction in viable organisms, but activity was not observed after 30 minutes when the samples diluted at 1:2 were tested.

The non-diluted samples of the 4 formulas showed different activity. The decimal reduction time (D-value), calculated for tests with a correlation coefficient higher or equal to 0.800 , showed the highest antimicrobial activity (D-value equal to 0.21 minutes) in formula 1. Formulas 2 and 3 presented similar D-values: 2.08 and 1.93 minutes, and formula 4 had the lowest activity against $A$. viscosus: D-values equal to 5.79 minutes, according Table III. Figure 2 shows the behavior of the challenged formulas employing

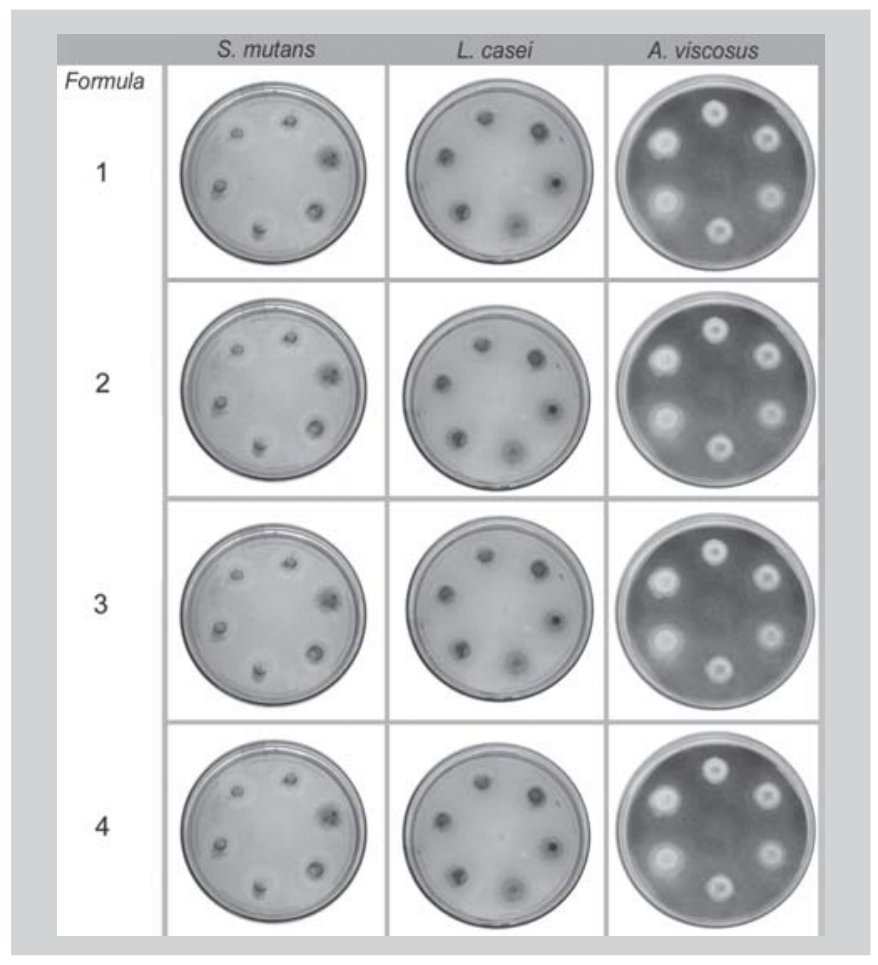

FIGURE 1 - Inhibition Zone for Formulas 1, 2, 3 and 4.

A. viscosus. Since the 3 formulas have the same formula base, differing only in flavor (information from the producer), the greater antimicrobial activity of formula 1 can be due to the essential oil employed in it. This result confirms that even products with the same base formula should be tested, since they can present different activities when any ingredient, such as flavor, is different.

Among the tested gels, formula 4 showed the lowest activity against these bacteria. Besides the flavor, this formula differs from the other 3 in relation to fluoride concentration, which was $33.3 \%$ lower. NaF gels with a fluoride concentration of 37,000 micrograms $/ \mathrm{mL}$ were bactericidal to $S$. mutans at $\mathrm{pH} 3.0$. At $\mathrm{pH} 2.5$ and 2.0, approximately 12,000 and 1,100 micrograms of fluoride per $\mathrm{mL}$ were bactericidal (Caufield, Wannemuehler, 1984), respectively. In this study, $\mathrm{pH}$ determinations showed values above 6.50 for all products tested: $6.64 \pm 0.08 ; 6.54$ $\pm 0.07 ; 6.65 \pm 0.06 ; 6.90 \pm 0.07$ for formulas $1,2,3$ and 4 , respectively. These results indicate that the observed antimicrobial activity in this study may not be related to the fluoride compound.

The data concerning $L$. casei and $S$. mutans revealed intense antimicrobial activity of diluted and non-diluted samples, with a reduction of 8 logarithmic cycles at 1 minute time intervals of the challenge (Table IV). Taking into account that the method employed for determining survivors was previously validated, according to official 
TABLE II - Number of Survivors (Log CFU/mL) of $A$. viscosus of the Challenge Test for Formulas 1, 2, 3 and 4

\begin{tabular}{|c|c|c|c|c|c|c|c|c|c|}
\hline \multirow{3}{*}{$\begin{array}{l}\text { Time } \\
\text { (minutes) }\end{array}$} & \multicolumn{9}{|c|}{ LogCFU/mL } \\
\hline & \multicolumn{2}{|c|}{1} & \multicolumn{2}{|c|}{2} & \multicolumn{2}{|c|}{3} & \multicolumn{2}{|c|}{4} & \multirow[t]{2}{*}{ Control } \\
\hline & ND & D & ND & D & ND & D & ND & D & \\
\hline 0 & 8.40 & 8.40 & 8.40 & 8.40 & 8.40 & 8.40 & 8.40 & 8.40 & 8.40 \\
\hline 1 & 3.66 & 8.66 & 4.04 & 8.38 & 5.30 & 8.81 & 5.40 & 8.54 & 8.40 \\
\hline 5 & - & 5.79 & 3.48 & 8.68 & 3.81 & 8.64 & 3.20 & 8.11 & 8.34 \\
\hline 10 & - & 5.48 & 2.08 & 8.63 & 2.26 & 8.36 & 3.00 & 8.08 & 8.32 \\
\hline 20 & - & 5.08 & - & 8.57 & - & 8.23 & 2.56 & 8.80 & 8.40 \\
\hline 30 & - & 5.00 & - & 7.58 & - & 8.00 & 1.30 & 8.58 & 8.36 \\
\hline
\end{tabular}

(-) non-calculated: < 10 UFC/mL. ND: non-diluted D: diluted $(1: 2)$

recommendations, the obtained data showed bactericide activity of the challenged formulas on the tested microaerophillic organisms.

All tested samples were active against these microorganisms, but it was not possible to detect differences among them since viable organisms were not observed in all samples, diluted at 1:2, that underwent counting after 1 minute. The activities of the 4 formulas may be different, but this could not be verified in the tested conditions. Differences could be obtained if the tests were performed with more diluted samples.

The 4 formulas antimicrobial activity is a result of all compounds, especially formaldehyde and sodium fluoride or sodium monofluoride activities, despite the fact these substances were added to the gels with the first aiming to preserve the product and the fluoride to protect the teeth, and not for activity against oral cavity organisms. The obtained data shows that the flavors used in the formulas also have antimicrobial activity, however, once again, the purpose for these compounds in the formulas was to

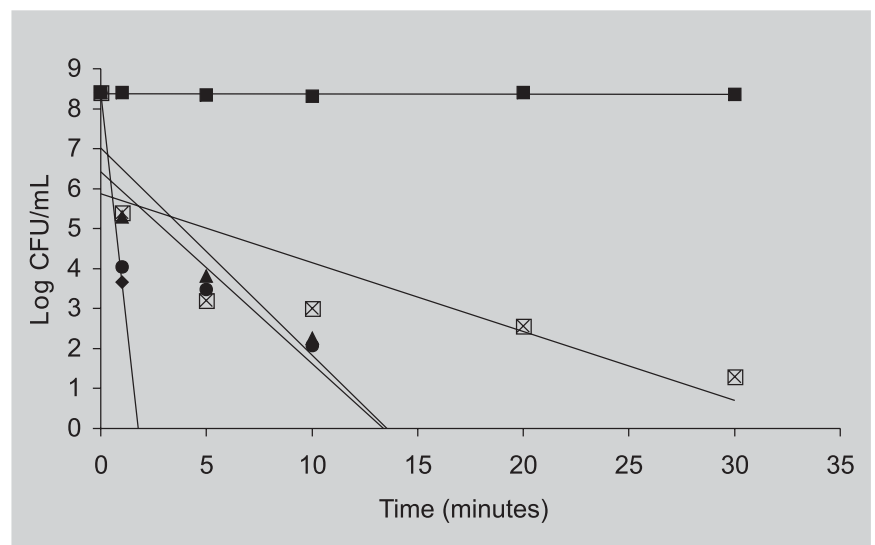

FIGURE 2 - Lethality Profile (LogCFU/mL x Minute) of Actinomyces viscosus for formulas $1(\bullet), 2(\bullet), 3(\mathbf{\Delta}), 4$ $(\times)$ and Control (ם).
TABLE III - D-value, Equation, and Correlation Coefficient for $A$. viscosus Challenge Test

\begin{tabular}{cccc}
\hline Formulas & $\begin{array}{c}\text { D-value } \\
\text { (minutes) }\end{array}$ & Equation & $\begin{array}{c}\text { Correlation } \\
\text { Coefficient }\end{array}$ \\
\hline $\mathbf{1}$ & 0.21 & $\mathrm{Y}=-4.7400 \mathrm{x}+8.4000$ & 1.0000 \\
$\mathbf{2}$ & 2.08 & $\mathrm{Y}=-0.4800 \mathrm{x}+6.4200$ & 0.8000 \\
$\mathbf{3}$ & 1.93 & $\mathrm{Y}=-0.5182 \mathrm{x}+7.0154$ & 0.8976 \\
$\mathbf{4}$ & 5.79 & $\mathrm{Y}=-0.1727 \mathrm{x}+5.8759$ & 0.8035 \\
\hline
\end{tabular}

improve taste.

Taking into account the data from $L$. case $i$ and $S$. mutans tests, the 4 formulas can be considered effective as antimicrobial dentifrices, since they all showed high activity against microorganisms present in the oral cavity, after 1 minute of contact, even when diluted to $1: 2$, a condition similar to the brushing of teeth. Analysis of the data obtained from the tests with $A$. viscosus showed that the 4 formulas are active against this microorganism, as per agar diffusion data and linear regression methods of the non-diluted samples. However, the 1:2 dilutions were not effective after a 30 -minute contact time, tested by the linear regression method. These data show the importance of analyzing the antimicrobial activity of products such as (toothpaste) by applying linear regression, since this test provides the profile for reducing the bioburden that may be analyzed according to product use needs. With regard to the obtained data, considering that the dental product will be diluted with saliva during use, and the time the product is kept inside the mouth is short, none of the tested formulas are effective as antimicrobial dental agents against $A$. viscosus.

On the other hand, data analysis should consider that no antimicrobial showed high activity against all microorganisms. Considering that the formulas were highly active against $L$. casei and $S$. mutans, the latter is 
TABLE IV - Number of Survivors (CFU/mL) of L. casei and S. mutans of the Challenge Test for the Formulas 1, 2, 3, 4

\begin{tabular}{|c|c|c|c|c|c|c|c|c|c|c|}
\hline \multirow[b]{2}{*}{ Formulas } & \multicolumn{2}{|c|}{$\mathrm{T}_{1}$} & \multicolumn{2}{|c|}{$\mathrm{T}_{5}$} & \multicolumn{2}{|c|}{$\mathrm{T}_{10}$} & \multicolumn{2}{|c|}{$\mathrm{T}_{20}$} & \multicolumn{2}{|c|}{$\mathrm{T}_{30}$} \\
\hline & ND & D & ND & D & ND & D & ND & D & ND & D \\
\hline 1 & $<10$ & $<10$ & $<10$ & $<10$ & $<10$ & $<10$ & $<10$ & $<10$ & $<10$ & $<10$ \\
\hline 2 & $<10$ & $<10$ & $<10$ & $<10$ & $<10$ & $<10$ & $<10$ & $<10$ & $<10$ & $<10$ \\
\hline 3 & $<10$ & $<10$ & $<10$ & $<10$ & $<10$ & $<10$ & $<10$ & $<10$ & $<10$ & $<10$ \\
\hline 4 & $<10$ & $<10$ & $<10$ & $<10$ & $<10$ & $<10$ & $<10$ & $<10$ & $<10$ & $<10$ \\
\hline L. casei & $4.6 \times 10^{8}$ & $5.1 \times 10^{8}$ & $4.8 \times 10^{8}$ & $5.0 \times 10^{8}$ & $4.7 \times 10^{8}$ & & & & & \\
\hline S. mutans & $8.6 \times 10^{8}$ & $7.8 \times 10^{8}$ & $8.8 \times 10^{8}$ & $7.5 \times 10^{8}$ & $7.7 \times 10^{8}$ & & & & & \\
\hline
\end{tabular}

ND: non-diluted

D: diluted (1:2)

considered to be the main organism responsible for caries, and also showed activity against A.viscosus, the 4 formulas could be considered antimicrobial dental gels. For the choice of the best formula, the linear regression data indicated Formula 1, showing the usefulness of this method for antimicrobial activity evaluation analysis of products considering the conditions of use.

\section{CONCLUSION}

The tested samples showed remarkable bactericide activity, in assay conditions, on S. mutans and L. casei. Besides the inhibition zone, the microbial death rate revealed a reduction of 8 logarithmic cycles at a time interval of 1 minute for those microorganisms. On the other hand, a decreased antibacterial activity was observed when A. viscosus was used. The data from tested samples showed that formulas with the same base, but different flavors, may have different antimicrobial activity, indicating the inhibitor properties of these compounds and the need for testing the formula, even when only the flavor is changed. Linear regression proved to be useful for testing products like dental gels, since it allows microorganism's behavior observed in the formula over time. Such an approach is important for analyzing products' antimicrobial activity, considering use conditions, especially in the preformulation stage.

\section{RESUMO}

\section{Atividade antimicrobiana de quatro formulações diferentes de géis dentais em bactérias cariogênicas avaliada pelo método de regressão linear}

A atividade antimicrobiana de quatro diferentes fórmulas de gel dental foi avaliada empregando três microrganismos associados à cariogênese: Streptococcus mutans, Lactobacillus casei $e$ Actinomyces viscosus. A avaliação pre- liminar foi efetuada utilizando método por difusão em ágar. Além disso, as fórmulas foram desafiadas empregando cada microrganismo e as determinações relativas aos sobreviventes foram efetuadas após 1, 5, 10, 20 e 30 minutos do desafio. O tempo de redução decimal (valor-D) foi calculado por meio das curvas obtidas (UFC/mL x tempo), objetivando a comparação da atividade antimicrobiana entre as fórmulas. O método selecionado para a enumeração dos sobreviventes foi validado de acordo com compêndio oficial. Os resultados revelaram intensa atividade antimicrobiana, inclusive na avaliação empregando diluição 1:2 dos produtos para os microrganismos Streptococcus mutans e Lactobacillus casei. Os dados relativos ao Actinomyces viscosus indicaram ausência de redução da população microbiana no desafio empregando produto diluido (1:2). Os valores-D obtidos foram 0,21, 2,08, 1,93 e 5,79 minutos para as fórmulas 1, 2, 3 e 4 respectivamente. Após comparação dos resultados obtidos, a fórmula 1 pode ser considerada aquela que apresentou maior atividade antimicrobiana.

UNITERMOS: Atividade antimicrobiana. Gel dental. Regressão linear. Validação.

\section{REFERENCES}

AKERS, M.J., BOAND, A.V., BINKLEY, D.A. Preformulation method for parenteral preservative efficacy evaluation. J. Pharm. Sci., Washington, v. 73, p.903-905, 1984.

ANVISA - Resolução - RDC n ${ }^{\circ}$ 481, de 23 de setembro de 1999 [on line]. Disponível em http:/ www.ANVISA.gov.br/481_99.htm. Acesso em: 06 fev.2004(a).

ANVISA - Resolução-RDC n ${ }^{\circ} 79$, de 28 de agosto de 2000 [on line]. Disponível em http:/e-legis.bvs.Br/leiref/public/ showAct.php. Acesso em: 05 fev.2004 (b). 
BALDANI, M.H.; NARVAL, P.C.; ANTUNES, J.L. Dental caries and socioeconomic conditions in the State of Parana, Brazil, 1996. Cad. Saúde Pública, Rio de Janeiro, v. 18, n. 3, p.755-763, 2002.

BANDEIRA, L.C.F.M.; OLIVEIRA, M.R.B.; PIZZOLLITO, C.A.; BENATTI, N.C. Estudo preliminar da atividade antibacteriana do óleo essencial e da resina da Copaifera multijuga (óleo de copaíba), associados ao óxido de zinco e ao hidróxido de cálcio. J. Bras. Cl. Est. Odontol., São Paulo, v. 3, n. 17, p. 46-52, 1999.

BARRY, L. A.; THORNSBERRY, C. Susceptibility test: diffusion test procedures. In: BALLOWS, A., HAUSLER, W.L., ISENBERG, D. H., SHADOMY, J. H., eds. Manual of Clinical Microbiology: ASM, Washington, 1991. p.1117-1125.

CANDIDO, C. R.; AZEVEDO, R.V.; ITO, Y. I. Determinação da concentração inibitória mínima de Cepacol, Malvona, Periogard, ante a Candida albicans isoladas da cavidade bucal. Rev. Odontol., São Paulo, v. 25, n. 1, p.79-84, 1996.

CAUFIELD, P.W.; WANNEMUEHLER, Y. pH-dependent bactericidal effects of acidulated fluoride gels on preformed plaque aggregates of Streptococcus mutans 6715. Antimicrob. Agents Chemother., London, v. 26, n. 6, p.807-810, 1984.

COOPER, L. R.; CHANG, D.B.; MARTIN, C. J.; ANCKERJOHNSON, B. Restricted diffusion in biophysical systems. Biophys. J., v. 14, n. 3, p.161-177, 1974.

CTPA - Cosmetic, Toiletry and Perfumery Products Association. [on line]. Available in: http:/ www.ctpa.org.uk/reg/define/bulk.htm. Acessed in: 02/05/ 2004.

DRAKE, T.E.; MAIBACH, H.I. Allergic contact dermatitis and stomatitis caused by a cinnamic aldehyde-flavored toothpaste. Arch. Dermatol., v. 112, n. 2, p. 202-203, 1976.

MANGENA, T.; MUYIAM, N.Y. Comparative evaluation of the antimicrobial activities of essential oils of Artemisia afra, Pteronia incana and Rosmarinus officinalis on selected bacteria and yeast strains. Lett. Appl. Microbiol., London, v. 28, n. 4, p.291-296, 1999.
MARCHANT, S. The predominant microflora of nursing caries lesions. Caries Res., v. 35, n. 6, p. 397-406, 2001.

MATTIE, M. Kinetic of antimicrobial action. Rev. Infect. Dis., v. 3, p.19-27, 1981.

MATTSON, M. A.; JENSEN, O. C.; DUTCHER, R.A. Triphenyltetrazolium chloride as a dye for vital issues. Am. J. Med. Sci., v. 106, p. 294-295, 1947.

NASCIMENTO, G.G.F.; LOCATELLI, J.; FREITAS, P.C.; SILVA, G.L. Antibacterial activity of plant extracts and phytochemicals on antibiotic-resistant bacteria. Braz. J. Microbiol., São Paulo, v. 31, n. 4, p. 247-256, 2000.

NOSTRO, A.; CANNATELLI, A. M.; MORELLI, I.; CIONI, P.L.; BADER, A.; MARINO, A.; ALONZO, V. Preservative properties of Calamintha officinalis essential oil with and without EDTA. Lett. Appl. Microbiol., London, v. 35, n. 5, p. 385-389, 2002.

OHARA, T. M. Aplicação do cloreto de trifeniltetrazólio no teste de limite microbiano em medicamentos e cosméticos. São Paulo, 1992, 211p. (Tese de Doutorado, Faculdade de Ciências Farmacêuticas, USP).

ORTH, D.S. Linear regression method for rapid determination of cosmetic preservative efficacy. J. Soc. Cosmet. Chem., New York, v. 30, p. 321-332, 1979.

POZZOBON, R. T.; BANDEIRA, M. F. C. L.; PIZZOLITTO, A. C. Análise comparativa da ação antibacteriana de agentes clareadores e soluções anti-sépticas. In: REUNIÃO ANUAL DA SOCIEDADE BRASILEIRA DE PESQUISAS ODONTOLOGICAS, 17, Águas de Lindóia, 2000. Anais. São Paulo: Sociedade Brasileira de Pesquisas Odontológicas, 2000.

RIOUX, J. A.; BASTIDE, J. M.; GALZY, P. La réductiona des sels de tétrazolium par les levures: application a la détermination rapide de quelques espêces du genre Candida. Trav. Pharm., Montpellier, v. 20, n. 1, p. 41-46, 1960.

SAEKI, Y.; ITO, Y.; SHIBATA, M.; SATO, Y.; OKUDA, K.; TAKAZOE, I. Antimicrobial action of natural substances on oral bacteria. Bull. Tokyo Dent. Coll., Tokyo, v. 30, n. 3, p. 129-135, 1989.

SAINIO, E.L.; KANERVA, L. Contact allergens in toothpastes and a review of their hypersensivity. Contact Dermatitis, Copenhagen, v. 33, n. 2, p.100-105, 1995. 
SHARMA, N.C.; CHARLES, C.H.; QAQISH, J.G.; GALUSTIANS, H.J.; ZHAO, Q.; KUMAR, L.D. Comparative effectiveness of an essential oil mouthrinse and dental floss in controlling interproximal gingivitis and plaque. Am. J. Dent., San Antonio. v. 15, n. 6, p.351-355, 2002.

SOFFRITTI, M.; BELPOGGI, F.; LAMBERTIN, L.; LAURIOLA, M.; PADOVANI, M.; MALTONI, C. Results of long-term experimental studies on the carcinogenicity of formaldehyde and acetaldehyde in rats. Ann. N Y Acad. Sci., New, York, v. 982, p.87-105, 2002.

TSUJI, A.; HAMAO, S.; ASANO, T.; NAKASHIMA, E.; YAMANA, T.; MITSUHASHI, S. Microbial kinetics of $\beta$-lactam antibiotic against Escherichia coli. J. Pharm. Sci., Washington, v.73, p. 418-1422, 1984.
UNITED STATES PHARMACOPOEIA. 24 ed. Rockville: United States Pharmacopeial Convention, 2000. p.18091818.

WILKINSON J.B.; MOORE, J. R. Cosmetología de Harry. Madrid: Diaz de Santos; 1990. 1093p.

ZAMBON, J.J.; KASPRZAK, S.A. The microbiology and histopathology of human root caries. Am. J. Dent., v. 8, p.323-328, 1995.

Recebido para publicação em 10 de fevereiro de 2004. Aceito para publicação em 15 de junho de 2005. 